\title{
ACCESS ALKALMAZÁS KIALAKÍTÁSA ÜGYFÉLKÖZPONTÚ SZOLGÁLTATÁSOK NYILVÁNTARTÁSÁRA
}

\author{
Fabulya Zoltán
}

Absztrakt: Az Access adatbázis-kezelő program segítségével olyan alkalmazásokat fejleszthetünk, melyek egy egyedi, testreszabott program szolgáltatásait képesek nyújtani felhasználóbarát módon. Bemutatásra kerül egy visszatérỏ ügyfélkör számára rendszeres szolgáltatásokat biztosító cég nyilvántartását kezelő alkalmazás: az alapját biztosító relációs adatbázis táblái és kapcsolatai, a funkciókat biztosító lekérdezések, ürlapok, jelentések és makrók. Végül áttekintjük az egyedi programként müködést jelentő beállításokat, mellyel bárki számára könnyen használható felületeket alakíthatunk ki a program egyszerủ kezeléséhez.

Abstract: Access database management software allows the development of customizable userfriendly applications. This paper presents the program of a firm providing regular services to manage recurring clients: the tables and relationships of the relational database providing the base, the queries providing the services and the forms, reports and macros as well. Finally, the settings are shown which allows the creation of easy-to-use user interfaces which enables anybody to control the program.

Kulcsszavak: Access, adatbázis, alkalmazás beállításai, kapcsolótábla

Keywords: Access, database, application settings, switchboard

\section{Bevezetés}

$\mathrm{Az}$ Access adatbázis-kezelő program méltatlanul nem örvend akkora népszerüségnek, mint amennyit az alkalmazásának lehetőségei biztosítanak (Hampel, 2017). Ez jelentős részben abból származhat, hogy az átlagos számítógép használók nem rendelkeznek azokkal az elméleti ismeretekkel, melyek nélkül nem tervezhető meg egy relációs adatbázist kezelő alkalmazás alapját biztosító táblák és kapcsolataik rendszere (Halassy, 1995).

Az elkészítendő alkalmazásban tárolnunk kell, hogy milyen időpontban, melyik alkalmazott, melyik ügyfélnek, mely szolgáltatást nyújtotta. Mindezt különböző típusú összesítésekkel visszakereshetően kell kialakítani úgy, hogy könnyen kezelhető, rugalmasan bővíthető legyen, alkalmazkodva az ügyfélkör, az alkalmazottak és a szolgáltatsok változásaihoz is.

\section{Anyag és módszer}

A bizalmas adatok védelme miatt csak a tervek, a kialakított funkciók, az alkalmazás beállításai és müködése kerülnek bemutatásra, a cég, valamint a konkrét szolgáltatási kör nélkül. Valójában bármely ügyfélközpontú szolgáltató cég számára hasznosítható az alkalmazás, mint például egy pénzügyi (Zsótér-Túri, 2017), egészségügyi szolgáltatások, vagy akár egy fodrász szalon esetében is.

A készítendő alkalmazás segítségével folyamatosan tárolni szeretnénk minden igénybevett szolgáltatásuk esetén:

- az ügyfél nevét,

- az ügyfél célját, azaz a szolgáltatás megnevezését, 
- az időpontot a dátummal együtt

- és hogy kihez érkezett, vagyis a szolgáltatást végző alkalmazott nevét.

Az adatok tárolásával lehetőségünk nyílik összesítésekkel, éves vagy havi bontásban hasznos információkhoz jutni a nyújtott szolgáltatások népszerűségéröl az alkalmazottak aktivitásáról stb.

Az Access 2010 programot használjuk az adatbázis kialakításához használatához. A tervező fázisban kell elkészítenünk az adatbázis összes olyar objektumát és az ezekhez szükséges kezelő felületet, melyek biztosítják egy laiku számára is az egyszerủ és jól áttekinthető használatot. Arról is gondoskodni kell hogy csak az adatokhoz legyen hozzáférése az objektumainkon keresztül felhasználónak, míg a tervek megváltoztatása kellő védettséggel rendelkezzen.

Több objektum típus szükséges az adatbázis megfelelő müködtetéséhez:

- tábla,

- lekérdezés,

- ürlap,

- jelentés,

- makró.

A táblák tárolják az adatainkat. A köztük lévő kapcsolatok kialakításhoz táblákban olyan mezőnek is lennie kell, mely elsődleges kulcsként alkalmazható azaz a tábla bármely rekordjának egyértelmű azonosítására képes.

Választó lekérdezésekkel gyüjthetünk ki táblákból és lekérdezésekből adatokal szürő feltételek megadásával, de számított és összesítő eredményeket képezhetünk. Akció lekérdezéseket futtatva a táblák adatait módosíthatjuk.

Ürlapokkal a táblák adatait tudjuk felhasználóbarát módon elérni többféle nézetben. Adatlap nézetben táblázatos formát kapunk, míg ürlap nézetben csak eg) sor (rekord) adatait szerkeszthetjük.

Jelentésekkel nyomtatáshoz szükséges elrendezést képezhetünk, csoportosító és összesítő beállításokat is megadhatunk. A legtöbb esetben persze nem a nyomtatá miatt, csak a monitoron megjelenítéshez alkalmazzuk.

Makrók segítségével speciális funkciókat alakíthatunk ki, melyek parancsol sorozatából állnak.

Az így elkészített objektumok menü jellegü elérését kapcsolótáblával oldhatjul meg. Az adatbázis olyan beállítása szükséges még, hogy indításkor ez kapcsolótábla, mint menü jelenjen meg, míg az objektumok tervéhez ne adjun hozzáférést.

\section{Eredmények és értékelésüik}

\subsection{Az adatrögzítés és adatkarbantartás eszközei, a táblák és ürlapjaik kialakítása}

Felmérve a használathoz szükséges funkciókat, először a táblákat és a köztük lévo kapcsolatokat (1.ábra) kell elkészítenünk. Ehhez azt is szem előtt kell tartani, hog! olyan felhasználóbarát módot szeretnénk, hogy lehetőség szerint gépelés helyet legördülö listás választást alkalmazhassunk. Ez indokolta, hogy az ügyfelek (Kliens) az igényelt szolgáltatás (Cél) és az ezt biztosító alkalmazott (Dolgozó) külön-külöt 
táblában legyen elérhető. Az adatbázisunk központi eleme az idő tábla, ami folyamatosan újabb adatokkal bővülve tárolja az érkező ügyfelek irányítását, vagyis, hogy a kliens milyen céllal, mikor (dátum), kihez érkezzen.

\section{1. ábra: Az adatbázis táblái és kapcsolatuk}

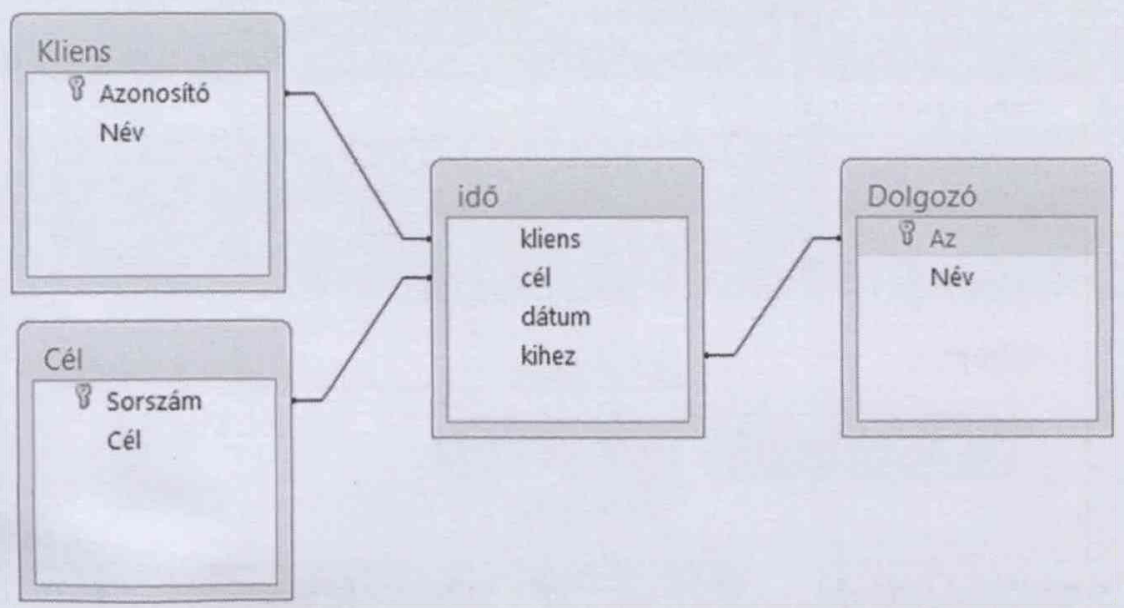

Forrás: A szerző saját szerkesztése.

Az 1. ábra dobozai egy-egy táblát szimbolizálnak a bennük tárolódó adattal, míg a köztük lévő vonalak a kapcsolatot jelentik az elsődleges kulcs szerepét betöltő mező segítségével

A tábla tervezésekor be kell állítani:

- a mezőket,

- a mezök adattípusát,

- az elsődleges kulcsot,

- az adatbevitel módját.

A Kliens táblában az elsődleges kulcs szerepét betöltő Azonosító mező számláló típusú, ami azt jelenti, hogy sorszám jellegủen automatikusan keletkezik egy következő érték minden újabb Név felvételekor. Tehát egy új ügyfél érkezésekor kell csak begépelni a nevét, és ekkor az Azonositó is értéket kap úgy, hogy a program használója számára meg sem kell jeleníteni. A Név mező szöveges adattípusú.

A Cél és Dolgozó táblák hasonlóak a Kliens táblához. Az idő táblában a kliens mező szám adattípusú, s az adatbevitel legördülő lista segítségével történik. A listában csak a Kliens táblában tárolt nevek jelennek meg, s a kiválasztott névhez tartozó Azonosító fog itt tárolódni, de a Név adata jelenik meg, mint kliens. Tehát a felhasználó itt sem látja az Azonosító értékét. Ugyanígy müködnek a cél és kihez mezők is. A dátum mező esetén sincs szükség begépelésre, mert itt automatikusan keletkezik az aktuális időpont a Now() függvénnyel. Amikor az idő táblában egy érkezö ügyfél esetén újabb rekordot kell rögzíteni, akkor a szükséges felületet biztosító ürlap $a$ 2. ábrán láthatóan jelenik meg ủrlap nézetben. 


\section{2. ábra: Ügyfél érkezésekor rögzítendő adatok ủrlapja}

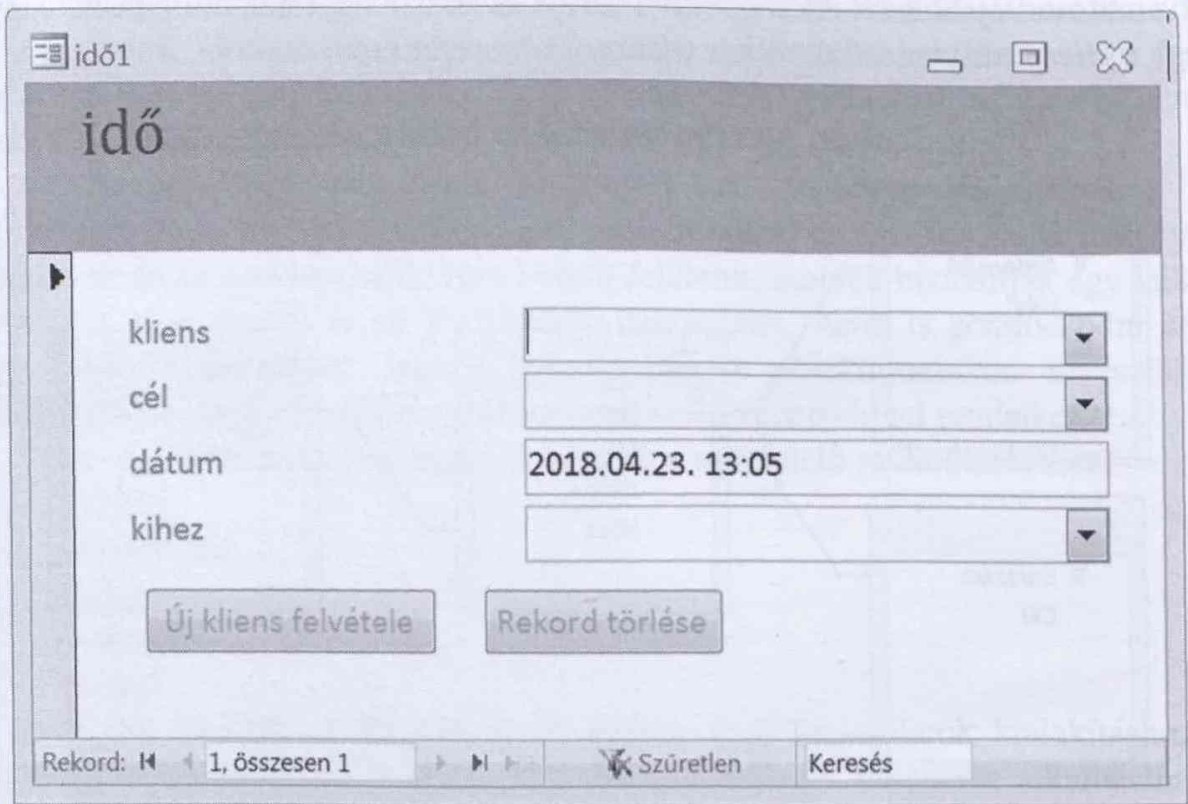

Forrás: A szerző saját szerkesztése.

Az ürlapon arra is van lehetőség az alul látható parancsgombokkal, hogy új kliens tudjunk felvenni, ha a legördülő listában nem jelenne meg (először jött), illetve törölni tudjunk egy rekordot hibás adatrögzítés miatt. Ezt a gombhoz rendelt makró segítségével tehetjük meg. Így megjeleníthetjük a kliens táblába adatrögzítést nyújtó ürlapot (3. ábra).

\section{3. ábra: Új kliens ürlapja}

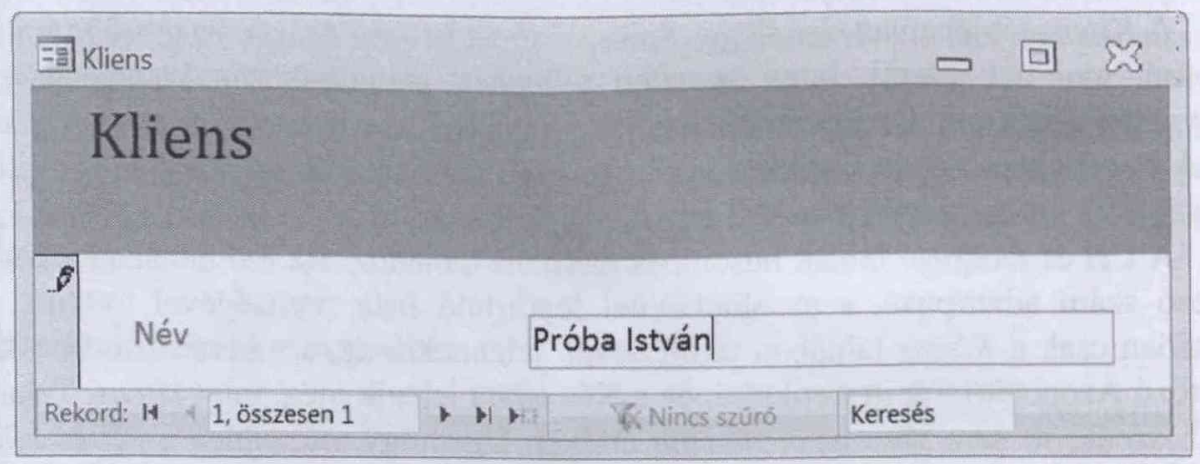

Forrás: A szerző saját szerkesztése.

Amennyiben mégis hibás adatokat rögzítettünk az idő táblába, akkor ezek törlésére alkalmas felületet is készíteni kell. Tapasztalat szerint ekkor elegendő, ha csak az utolsó őt rekord törlését kínáljuk fel úgy, hogy elsőként az időrendben 
utoljára rögzített rekord jelenjen meg (4. ábra). Ezt úgy tudjuk kialakítani, hogy először elkészítjük azt a lekérdezést, mely az utolsó öt rekordot dátum szerint csökkenően eredményezi, majd a lekérdezésen alapuló ürlapot készítjük el léptető gombokkal és a törlés parancsgombjával.

\section{4. ábra: Rekord törlésének ürlapja}

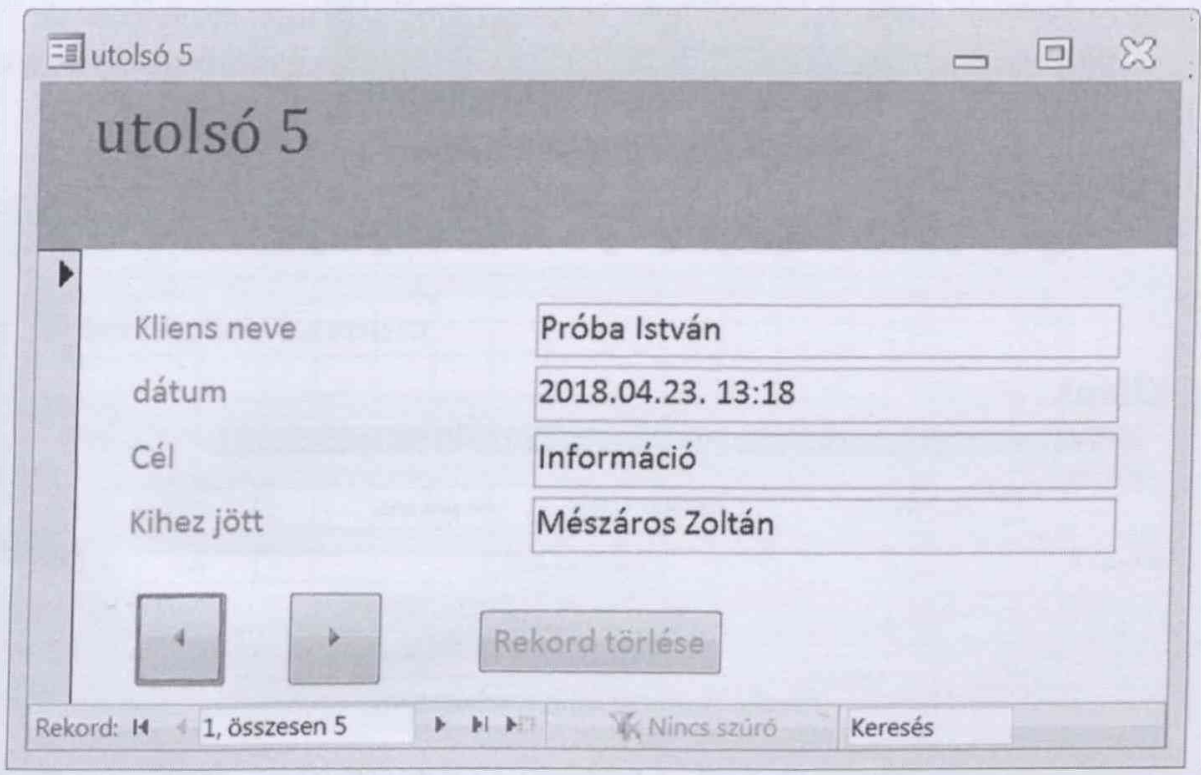

Forrás: A szerző saját szerkesztése.

\subsection{Adatkereső, összesítő funkciók}

A már rögzített adatokból különböző igények szerint szürt és összesített eredményeket képezhetünk, akár nyomtatásra alkalmas módon. Ezeknél a funkcióknál végső eredmény egy jelentés lesz csoportosító és csoportonként összesítést adó beállításokkal szükség esetén, melynek alapja egy olyan lekérdezés, melyben a szürés feltételét paraméterként tudja a felhasználó megadni. Ilyen funkció például a kliens keresése. Itt a szürési feltétel paramétereként a kliens nevét vagy annak kezdő karaktereit adhatja meg a felhasználó (5. ábra), s megjelenik az összes olyan rekord kliensenként csoportosítva (6. ábra), ahol teljesült a feltétel. 


\section{5. ábra: Feltétel megadása}

\begin{tabular}{|c|c|}
\hline Paraméter megadása & ? $x$ \\
\hline kit keresünk & \\
\hline Próba I*1 & \\
\hline OK & Mégse \\
\hline
\end{tabular}

Forrás: A szerző saját szerkesztése.

\section{6. ábra: Keresett kliens eddigi időpontjai}

\section{Kliens}

\begin{tabular}{|c|c|c|c|}
\hline Kliens.Név & Cél & datum & Dolgozó.Név \\
\hline
\end{tabular}

2018. majus 23.

Forrás: A szerző saját szerkesztése.

Részletesen nézzük meg annak a funkciónak a kialakítását, mely az új ügyfél felvételeket összesítetten eredményezi. Ehhez elsőként a lekérdezést kell elkészíteni (7. ábra).

\section{7. ábra: Új felvételek lekérdezése összesítéssel lekérdezés tervező nézete}

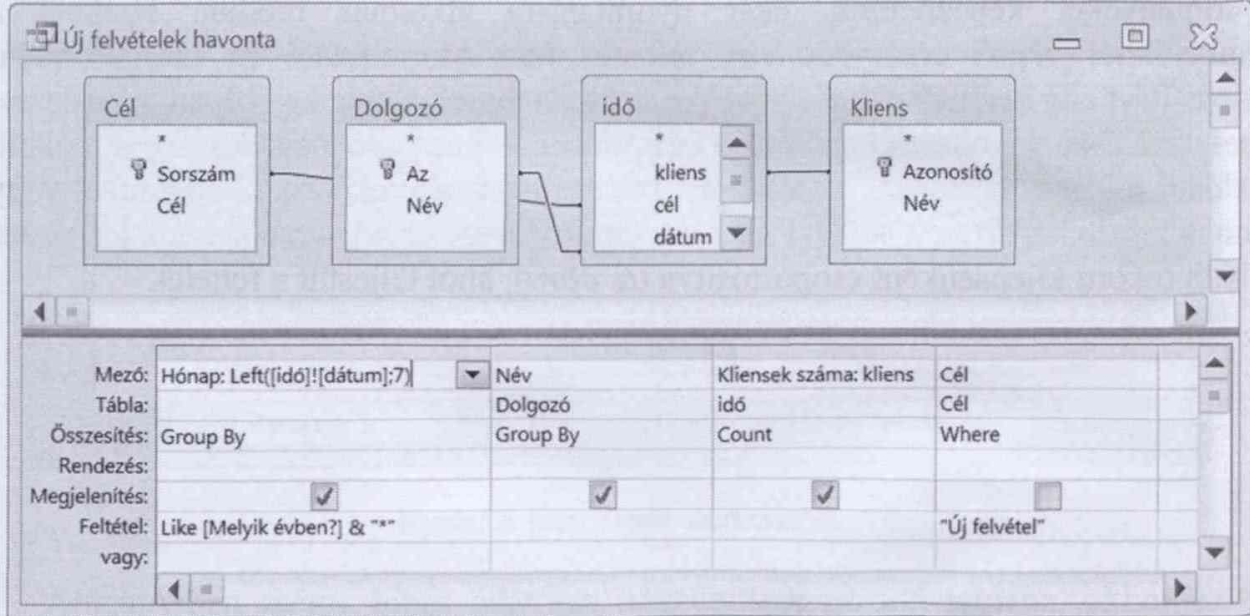

Forrás: A szerző saját szerkesztése. 
A lekérdezés tervező nézetének utolsó oszlopában szerepel az „Új felvétel” feltétel. Az első oszlopban további feltételként paraméterként alakul ki a [Melyik évben?] kérdésre kapott válasz. Itt a dátum mezőben tárolt adat baloldali első 7 karaktere lesz az adat, ha a feltétel évével egyezik. A második oszlop beállítása eredményezi, hogy a dolgozó neve alapján csoportok alakulnak ki (Group by), míg a harmadik oszlopban az egy csoportba tartozók darabszámát (Count) kapjuk.

A lekérdezés adja az alapját annak a jelentésnek (8. ábra), mellyel megkapjuk havi csoportosításban a dolgozók nevét és az új felvételü klienseik számát.

\section{8. ábra: Jelentés tervezỏ nézete}

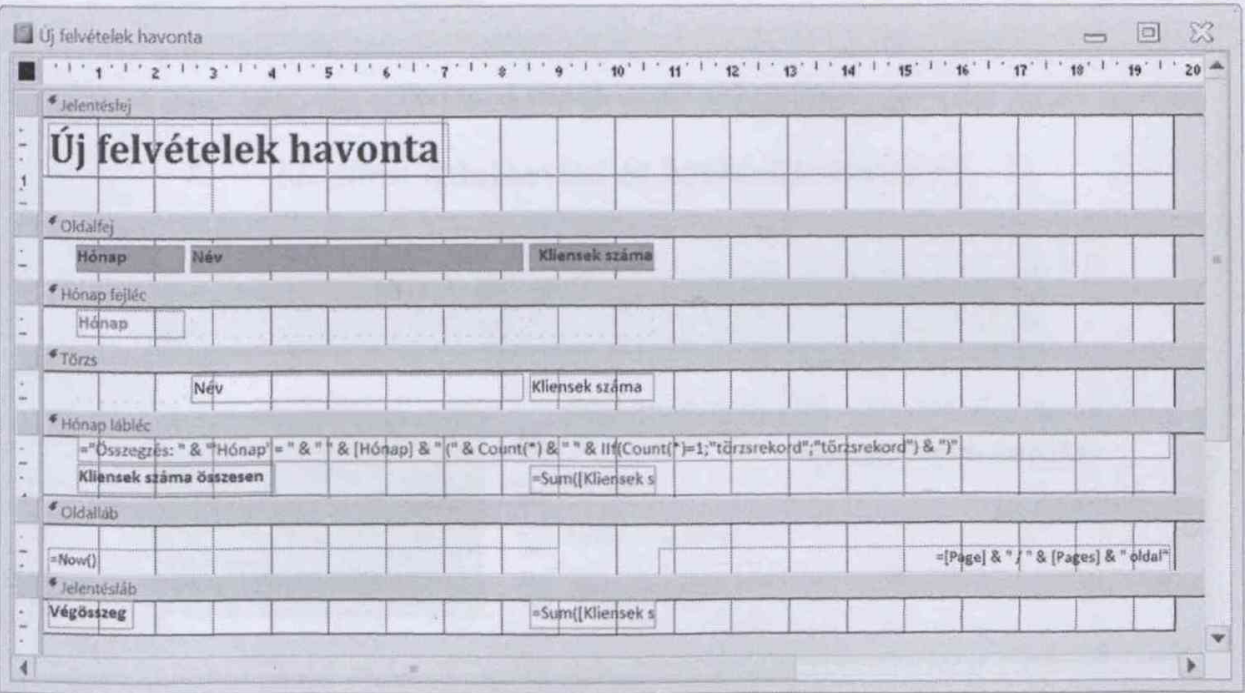

Forrás: A szerző saját szerkesztése.

A felhasználó számára a jelentés nyomtatási képe adódik (9. ábra). A dolgozók nevei nem publikusak.

További összesítésekkel hasonló funkciók készíthetők:

- Dolgozók havi feladatai.

- Kliensek száma havonta.

- Célok száma havonta.

- Éves összesítés. 


\section{9. ábra: Jelentés nyomtatási képe}

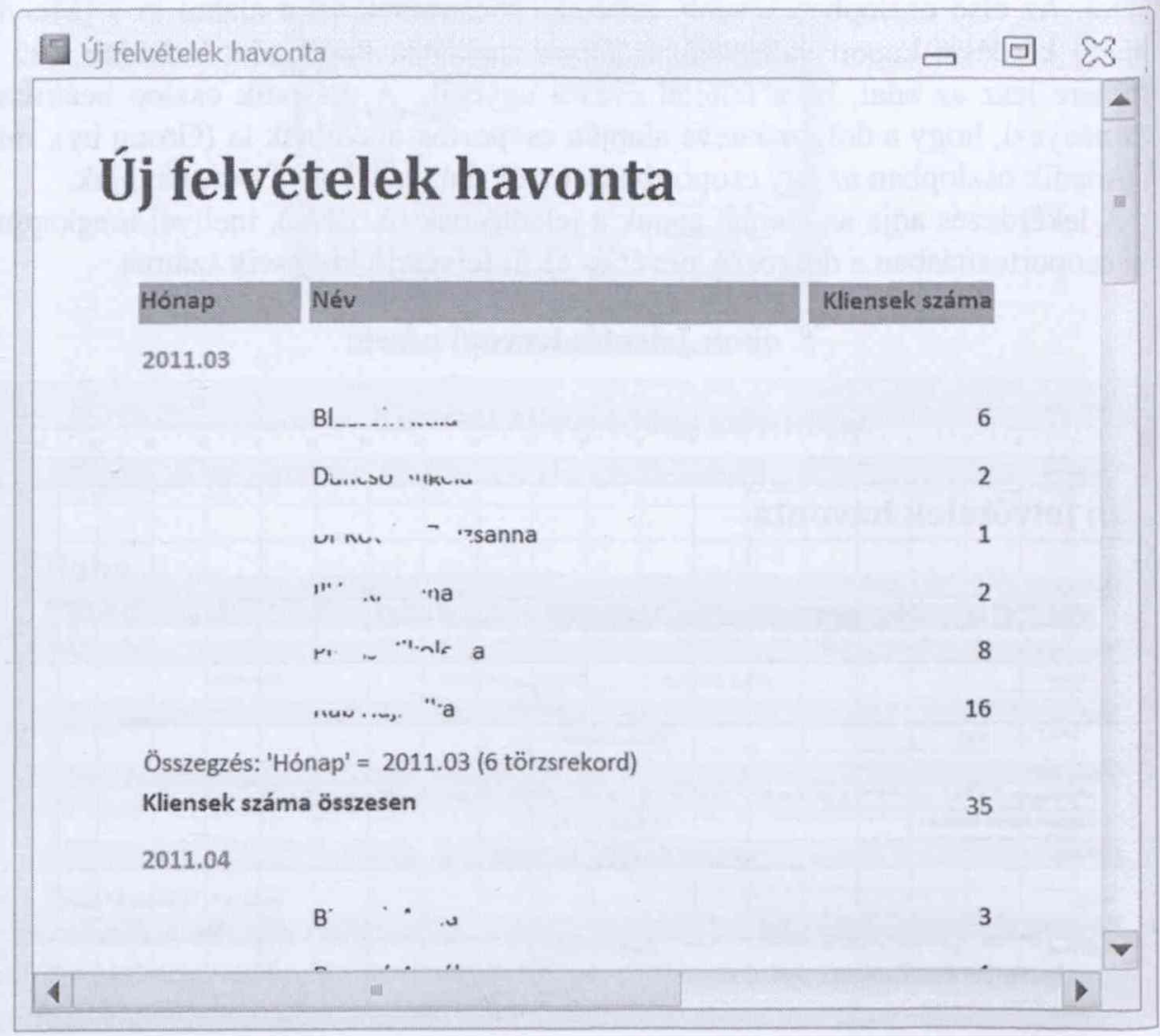

Forrás: A szerző saját szerkesztése.

3.3. Kapcsolótábla, avagy menü készítése a funkciókhoz

Hogy a felhasználó ne tudjon a terveken módosítani, és csak a számára kialakítot funkciókat érje el, ki kell alakítanunk kapcsolótáblákat a megfelelő menüpontokkal míg az objektumok tervező nézetét le kell tiltani. Végül indítási beállításkér érhetjük el, hogy az adatbázis megnyitásakor a főmenü kapcsolótáblája (10. ábra jelenjen meg.

Az ábrán látható, hogy két csoportban kaptak helyet a funkciók:

- Adatbevitel és karbantartás.

- Lekérdezések.

Ezekkel további kapcsolótáblákra (11. és 12. ábra) léphetünk, míg azokró vissza. 


\section{0. ábra: A fömenü kapcsolótáblája}

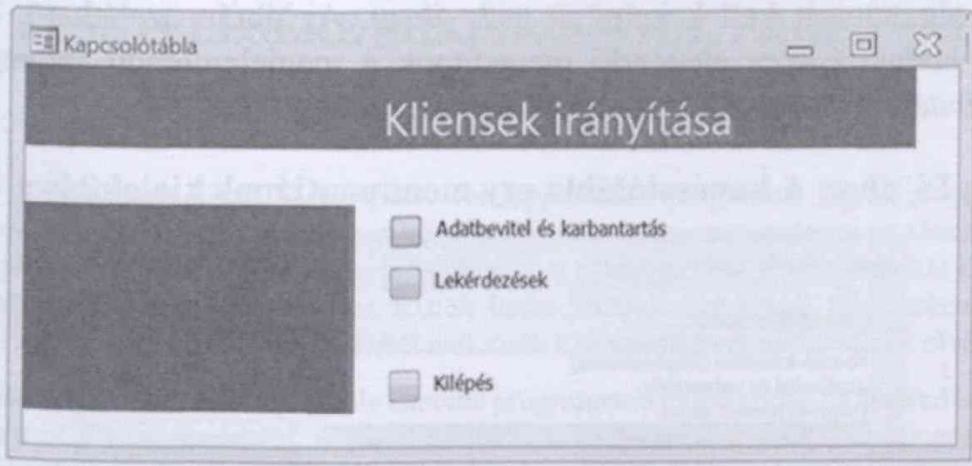

Forrás: A szerzỏ saját szerkesztése.

\section{1. ábra: Adatbevitel és karbantartás menü}

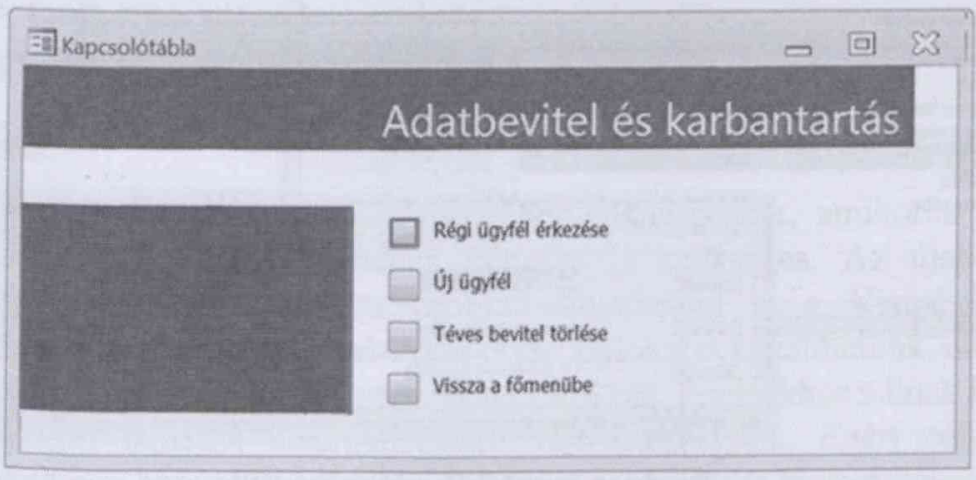

Forrás: A szerző saját szerkesztése.

12. ábra: Lekérdezések menü

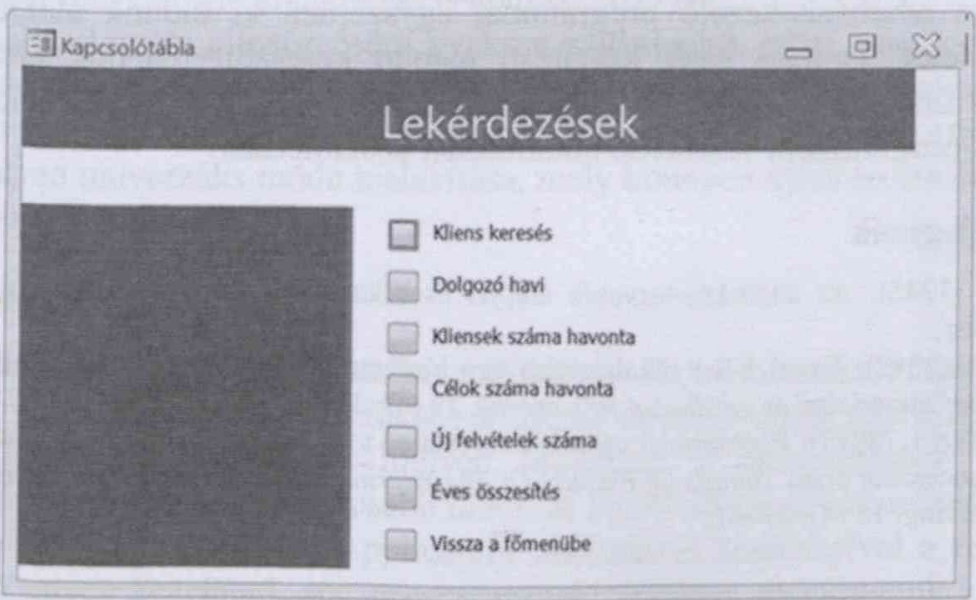

Forrás: A szerző saját szerkesztése. 
Ahhoz, hogy egy kapcsolótáblát elkészítsünk, csak az Access „kapcsolótábl kezelö" szolgáltatását kell kezelnünk (13. ábra). Az ábrán az látható, hogy eg) menüpont kialakításakor elegendő megadnunk a megjelenítendő szöveget, maj legördülő listából kiválaszthatjuk a szükséges elemeket.

\section{3. ábra: A kapcsolótábla egy menüpontjának kialakítása}

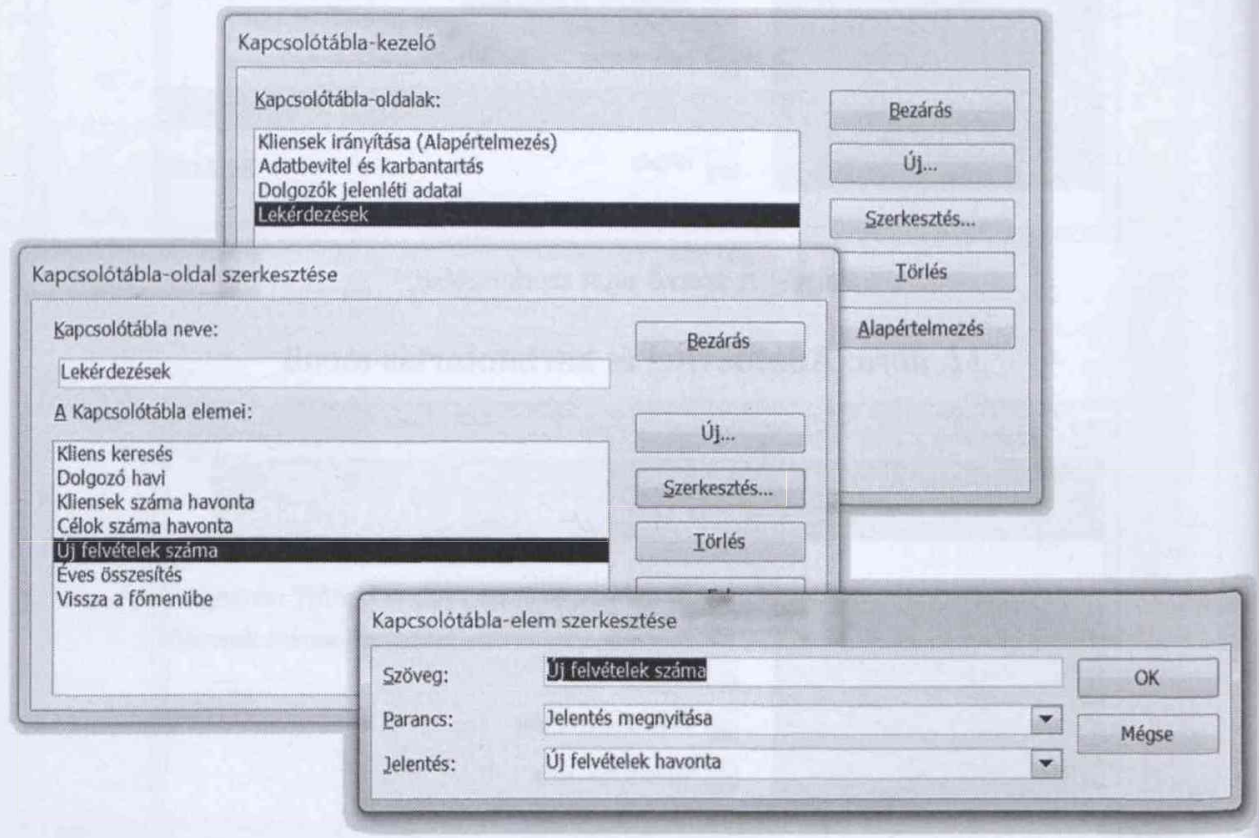

Forrás: A szerző saját szerkesztése.

\section{Következtetések, összegzés}

Az Access adatbázis-kezelő programmal egyszerüen ki tudunk alakítani olya kezelőfelületet, mellyel saját készítésủ menün keresztül tehetjük elérhetővé ? kialakított funkciókat. Így egy átlagos számítógép használó számára is könnyen kezelhető, programként viselkedő alkalmazást készíthetünk.

\section{Irodalomjegyzék}

Halassy B. (1995): Az adatbázis-tervezés alapjai és titkai. IDG Magyarországi Lapkiadó Kfl. Budapest.

Hampel Gy. (2017): Excel VBA alkalmazása egy biometriai esettanulmány példáján bemutatva Jelenkori társadalmi és gazdasági folyamatok, 12 (4): 35-40.

Zsótér B., Túri I. (2017): Economical calculations related to a smoking technology investment of pork processing plant. Annals of Faculty Of Engineering Hunedoara - International Journal 0 . Engineering, 15 (4): 57-61. 